\title{
Control criteria of electrochromic glasses for energy savings in mediterranean buildings refurbishment
}

\author{
Paulo Tavares ${ }^{\mathrm{a}, \mathrm{b}, \mathrm{c}, *}$, Hermano Bernardo ${ }^{\mathrm{b}}$, Adélio Gaspar $^{\mathrm{c}}$, António Martins ${ }^{\mathrm{d}, \mathrm{b}}$ \\ ${ }^{a}$ Electrical Engineering Department, Coimbra Institute of Engineering - Polytechnic Institute of Coimbra, Rua Pedro Nunes - Quinta da Nora, \\ 3030-199 Coimbra, Portugal \\ ${ }^{\mathrm{b}}$ INESC Coimbra - Institute for Systems Engineering and Computers at Coimbra, Portugal \\ ${ }^{\mathrm{c}}$ ADAI, LAETA, Department of Mechanical Engineering, University of Coimbra, Portugal \\ ${ }^{\mathrm{d}}$ Energy for Sustainability Initiative, University of Coimbra, Portugal
}

Received 10 November 2015; received in revised form 15 April 2016; accepted 16 April 2016

Available online 13 May 2016

\begin{abstract}
During the next decades the refurbishment of old buildings will be an essential way to contribute to the global improvement of buildings energy performance indicators. Within this context, the present paper is focused on the use of electrochromic (EC) windows, an emerging technology alternative to shading devices, to control solar gains in buildings located in Mediterranean climates. The optical properties adjustments of the EC glasses are discussed based on the incident solar radiation. The ESP-r building energy simulation software was used to study the energy savings resulting from the application of electrochromic windows, considering the comparison of several windows solutions (single, double-glazing and EC windows) and windows orientations (East, South and West). In addition, different transition ranges for the optical properties of the EC glasses are assessed through the analysis of the energy needs for space heating and cooling. The main conclusion is that EC technology is an effective option in cooling dominated buildings. The impact of EC windows is highly dependent on facade orientation, being a valid option particularly in the cases of the East and West facades. For these facades, the control set point found to be effective corresponds to an incident solar radiation on the glass of $150 \mathrm{~W} / \mathrm{m}^{2}$ to impose a total coloured state. For the South facade the results show no significant advantage of using EC windows.
\end{abstract}

(C) 2016 Elsevier Ltd. All rights reserved.

Keywords: Building refurbishment; Solar gain control; Electrochromic windows; Building energy performance simulation

\section{Introduction}

Windows and glazed surfaces are the elements of the buildings envelope that require more attention at design, specification and operation, since the control of both thermal losses in the heating season and solar heat gains in the cooling season are crucial for the thermal behaviour of

\footnotetext{
* Corresponding author at: Electrical Engineering Department, Coimbra Institute of Engineering - Polytechnic Institute of Coimbra, Rua Pedro Nunes - Quinta da Nora, 3030-199 Coimbra, Portugal.

E-mail address: ptavares@isec.pt (P. Tavares).

$U R L:$ http://www.isec.pt (P. Tavares).
}

buildings. It is not an easy task to settle the dimensions of the glazed areas in such a way as to balance the energy consumption of the heating, ventilation and air conditioning (HVAC) systems and the use of daylight to minimize energy use for artificial lighting, simultaneously providing high visual comfort (Ochoa et al., 2012). Moreover, labour productivity is higher in the presence of daylight and the possibility of seeing the exterior surroundings (Ochoa et al., 2012). Keeping this in mind, several studies using building energy dynamic simulation have been performed to assess the energy impact of using more efficient glazing systems (Freire et al., 2011), the general conclusion being that the replacement of existing single glazing windows 
by double glazing windows appears to be an effective solution (Rahman et al., 2010).

To address such problems, new window solutions have been developed (Gil-Lopez and Gimenez-Molina, 2013; Gao et al., 2014) and the performances of different kinds of shading devices were also studied in different climatic conditions and facade orientations (Palmero-Marrero and Oliveira, 2010; Huang et al., 2014). The intelligent control of shading devices and openings in order to optimize comfort and minimize energy demand was recently studied in Denmark (Liu et al., 2015).

This paper presents a study aiming at answering the following research question: what is the most suited control strategy to apply to electrochromic (EC) glasses and what is the influence that internal loads may have on their operation in the Mediterranean climate, taking into account the influence of the facade orientation? The obtained results may contribute to the future automation of such electrochromic devices, that can be controlled by Building Automation and Control Systems (BACS) (Marinakis et al., 2013), using the information gathered from solar radiation sensors located on the facades.

Some of the works analysed present a comparison between static and dynamic glazing solutions (Hee et al., 2015) in several climates (DeForest et al., 2013). These comparisons have frequently been made through the use of simulators (DeForest et al., 2013) and/or based in previous works (Hee et al., 2015). Some works tried to validate the simulated results by comparison with experimental data (Jelle, 2013), having as main goal to explain the dynamics of the EC glass, its properties and how it behaves (Jelle, 2012, 2013). The works of Lee et al. (2012) and Kelly et al. (2013) present a pilot building retrofitting replacing single glass with double EC glass from $\mathrm{SAGE}^{\mathrm{TM}}$. In this open space office case study some measurements were made. Jelle (2012) shows how EC glass can be used in building refurbishment and presents a complete review of dynamic glass solutions (special glasses). These works show that glazing with controllable properties is a suitable technology for energy control in buildings and aims at overcoming the challenges mentioned for conventional glazing, still with similar functionality and properties.

Aldawoud (2013) makes an analysis based on simulation of solar gains in space zones at the East, South and West facades, comparing conventional shading systems with EC glasses in hot and dry climates.

EC glasses need a control strategy to manage when they should be in the coloured or in the clear state (Roos et al., 2005a). This strategy can be based on several parameters, one of which is occupant's preference, which is unpredictable. Minimizing energy consumption is not necessarily the occupants' main goal. Reducing reflections and/or glare could be the major factor for those working on computers, while interior temperature could be the most important for other occupants (Selkowitz and Lee, 2004; Lee et al., 2006). The physical or time-related parameters that can be used to control EC glasses are, according to Roos et al. (2005a), solar irradiation, external temperature, indoor temperature, indoor light level, occupation profile, time of the day and season. Different adjustments and control algorithms correspond to each one of these parameters. Moreover, the system should have a response in such a way that it does not react to short duration changes, such as a cloud covering the sun for a short period of time. As the switching time is several minutes, a high time constant should be used to control the EC glass, in order to avoid frequent changes (Roos et al., 2005a).

One of the goals of Fernandes et al. (2013) in the control of the EC glass is to maximize thermal comfort and the use of daylighting, without concern on reducing energy consumption. Sbar et al. (2012) simulates EC glasses (data from $\mathrm{SAGE}^{\mathrm{TM}}$ ) in East, South and West facades, in different climates, with the goal of maximizing daylighting and minimizing electrical energy consumption for lighting.

Some works just use value of the solar incident radiation to control EC glasses, which is a reductionist approach (Sullivan et al., 1994, 1996; Karlsson, 2001; Gugliermetti et al., 2002; Tavil and Lee, 2005; Assimakopoulos et al., 2007; Jonsson and Roos, 2010).

It is of interest for this study that the transition time depends on the EC glass area (Rottmann et al., 2005), materials and temperature (Lee et al., 2000; Lee and DiBartolomeo, 2002; Bell et al., 2002). It is possible to keep the device at any of the intermediate states. For a $10 \mathrm{~cm} \times 30 \mathrm{~cm}$ glass, $300 \mathrm{~s}$ are necessary for full colouring or bleaching (Rottmann et al., 2005); for a $1.2 \mathrm{~m} \times 0.8 \mathrm{~m}$ size electrochromic element, $20 \mathrm{~min}$ is needed for one complete switching cycle (colouring and bleaching). The colouring step takes $12 \mathrm{~min}$ and the bleaching step takes 8 min (Kraft and Rottmann, 2009). EC glasses could have two main states: completely coloured and completely clear. According to Rowley and Mortimer (2002), Argun et al. (2004) and Jelle $(2012,2013)$, different colours are possible (blue, yellow, green, red, grey, etc.) allowing architects to create diverse external building appearances. Furthermore, Argun et al. (2004) stated that an EC glass composed of conjugated polymers is the most suitable to change its structure creating different colours. When a material can have more than two electrochemical states, it can present several different colours, being designated polielectrochromic (Rowley and Mortimer, 2002). Despite some of these colour possibilities being still under development, some manufacturers have already some commercial solutions available, such as E-Control ${ }^{\circledR} \mathrm{GmbH} \& \mathrm{Co}$. KG (EControl, n/a), Gesimat GmbH (Gesimat, 2012) and SAGETM Electrochromics, Inc. (SAGE, n/a) with colours varying from "transparent" (clear) to blue (coloured).

The lifetime of this technology is currently estimated to be 20-30 years. The tests are made with millions of cycles. The most common is to consider 5 cycles per day. Companies such as SAGE ${ }^{\mathrm{TM}}$ Electrochromics, Inc. (SAGE, n/a), E-Control ${ }^{\circledR} \mathrm{GmbH} \&$ Co. KG (EControl, n/a) and Gesimat GmbH (Gesimat, 2012) warrant their EC glasses for 10 years (Baetens et al., 2010; Ritchie, 
2010). SAGE ${ }^{\mathrm{TM}}$ warrants the control electronics of their products for five years (Baetens et al., 2010).

For a large scale utilization of electrochromic glazing, as studied in the present paper, further development is required on materials used for glass manufacturing, as can be concluded from the work of Lin and Wang (2015).

Regarding users acceptance of EC technology, some studies can be found in the literature, as for instance, Sottile (2002, 2005), Tenner and Zonneveldt (2002), Clear (2006), Clear et al. (2006), Zinzi (2006), Rottmann et al. (2007), Piccolo and Simone (2009) and Granqvist et al. (2010). All these authors refer that the users of the buildings with EC glasses like this technology, mainly because it reduces glare, reflections and discomfort near the windows. All the aforementioned studies always include a field study with observation and inquiries to the building users.

The present study was motivated by the gap found in the literature about extensive research to evaluate the energy effects of the use of EC glasses in buildings, namely in Mediterranean climates. In this context, the evaluation of the EC technology in the retrofitting of historic heritage buildings is of particular interest, since the use of EC technology can be a solution to overcome the physical and architectural restrictions of such historic heritage buildings, improving their energy performance without aesthetical modifications.

The present work is focused on building retrofitting, that have usually constraints related to the application of conventional shading devices. The EC glass could bring application benefits and considerable potential for energy consumption reduction in existing buildings through retrofitting interventions (Burton, 2001; Pfafferott, 2004).

On the other hand, in previous works the authors find that the best physical parameter to control the EC glasses state is the incident solar radiation (Tavares et al., 2011, 2014). Therefore, in this work the authors explored a wide range of set points of solar incident radiation on the glass, in order to control the EC glasses states in each facade.

The paper is made up of four sections. The first section, the Introduction, provides some background on the studied subject. The second section presents the Methodology (simulation tool, building model and control of the EC glass). Results and discussion are presented in the third section (for two static solutions - single and double glass, and for EC double glass - a dynamic solution with different control ranges). Finally, conclusions are presented in the fourth section.

\section{Methodology}

Using building energy performance simulation, the present paper assesses the use of different types of window glass technologies. Single and double glass with static optical properties and double glass with dynamic optical properties - electrochromic (EC) glass - were considered in the building energy performance simulations. The objective was to understand how the controlled EC glass could increase the energy efficiency of buildings, particularly in a retrofitting context.

The single glass is the current solution for the fenestration of the majority of commercial and institutional buildings built in the middle of the last century, corresponding to the main building stock candidate for refurbishment during the next decade in Portugal and in many other Mediterranean countries. Therefore, the single glass was considered the reference solution for comparisons, results presentation and discussion.

The other static solution studied is double glazed windows. It was designated "conventional" or "current" double glazing because it considers a clear double glass without improved performance/characteristics. In Portugal this is the solution commonly used in building retrofitting to replace single glass.

The results of simulations performed in Tavares et al. $(2011,2014)$ show that the best physical parameter to control the EC glasses state is the incident solar radiation. EC glasses controlled by indoor temperature would not be effective in situations of conditioned spaces, being only effective in passive building operation.

From the literature review it is apparent that there are different criteria used in EC glasses control according to incident radiation intensity, which vary according to the climate data. Sullivan et al. $(1994,1996)$ refer $189 \mathrm{~W} / \mathrm{m}^{2} / 315$ $\mathrm{W} / \mathrm{m}^{2} / 630 \mathrm{~W} / \mathrm{m}^{2}$ (correlated with window size) for upper thresholds for transition to the coloured state; Karlsson (2001) refers thresholds of $50 \mathrm{~W} / \mathrm{m}^{2}$ (clear state) and $300 \mathrm{~W} / \mathrm{m}^{2}$ (coloured state); Gugliermetti et al. (2002) refer thresholds between 100 and $850 \mathrm{~W} / \mathrm{m}^{2}$ (for coloured state, dependent on the facade); Tavil and Lee (2005) refer $63-315 \mathrm{~W} / \mathrm{m}^{2}$ or $63-95 \mathrm{~W} / \mathrm{m}^{2}$ (for clear and coloured states); Assimakopoulos et al. (2007) refers $350 \mathrm{~W} / \mathrm{m}^{2}$ (coloured state); Jonsson and Roos (2010) refers $200 \mathrm{~W} / \mathrm{m}^{2}$ (coloured state).

Therefore, in the present study different solar radiation thresholds for the control of EC glass state transition were tested in order to identify the solution that leads to the best results. Additionally, the behaviour and impact of the EC windows orientation in the buildings energy needs were studied for East, South and West facades.

Building energy simulations were carried out on a testcell considered representative of a typical thermal zone of the Faculty of Arts and Humanities' building of University of Coimbra, which should be submitted to refurbishment in the near future. The test-cell model was based on the typical characteristics of the building, with square layout that enables to change the orientation, keeping the facade area. This was required in order to assess the solar gains effect on energy performance in East, South and West orientated window facade. The height and glazing ratio per facade of the test-cell was the same of a typical room of the existing building is also the same. The internal gains schedules for occupation, lighting and equipment were estimated based on the average values accordingly to an energy audit performed to the building. 
In order to analyse the influence of each type of glazing in the building thermal performance, three similar test-cells were used, differing in the glazing type (single, double and double EC). The test cells were adequately spaced to prevent mutual influences and no shading devices were considered.

\subsection{Simulation tool and building model}

Based on the work performed by Crawley team (Crawley et al., 2005a,b, 2008), where several building simulations programs characteristics and simulation performances were compared, the ESP-r for Linux ${ }^{\mathrm{TM}}$ simulation software was chosen. The ESP-r is developed by the "Energy Systems Research Unit" (ESRU), University of Strathclyde - Scotland, available at no cost under an open source license.

To perform the simulations a building model was defined with three independent single-room blocks of a square-shaped floor area (see Fig. 1), which differ only in the type of window glazing. The room dimensions and construction characteristics were based on a typical school building dated of the nineteen fifties.

Model characteristics:

- Zone dimensions $(W \times D \times H): 7 \mathrm{~m} \times 7 \mathrm{~m} \times 4 \mathrm{~m}$;

- Exterior walls: limestone coated with plaster, $60 \mathrm{~cm}$ thick $\left[U_{\text {value }}=1.90 \mathrm{~W} /\left(\mathrm{m}^{2} \mathrm{~K}\right)\right]$;

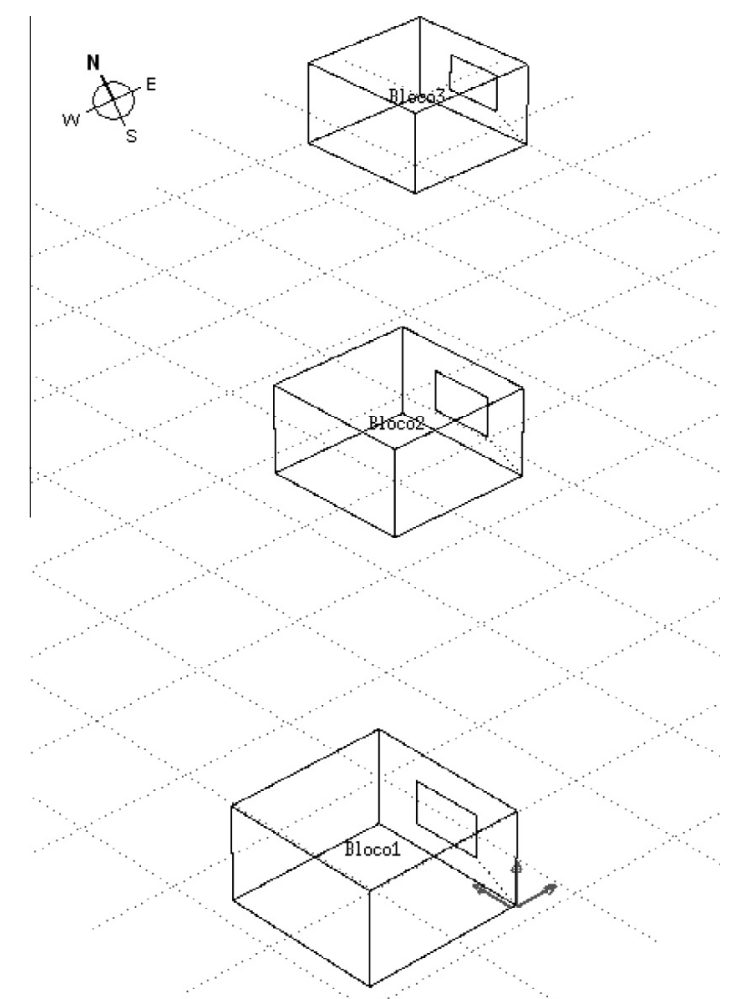

Fig. 1. Example of ESP-r model, with the three independent single-zones; case of windows on the East facade.
- Ceiling and floor: typical mid-floor construction (plaster, concrete and wood), $15 \mathrm{~cm}$ thick $\left[U_{\text {value }}=2.62 \mathrm{~W} /\left(\mathrm{m}^{2} \mathrm{~K}\right)\right]$; boundary conditions are considered similar - in the simulation process, a thermal zone with identical environmental thermal conditions is considered adjacent to the simulated thermal zone (Clarke, 2001);

- Window dimensions $(W \times H)$, model 1: $3.0 \mathrm{~m} \times 1.8 \mathrm{~m}$, placed at $1 \mathrm{~m}$ from the floor and centred on the facade;

- Outside air infiltration: a constant value of $0.6 \mathrm{~h}^{-1}$;

- Weather file: Coimbra_PRT (latitude: $40.210 \mathrm{~N}$; longitude: $8.430 \mathrm{~W}$ ).

This type of analysis is commonly developed using, not commercially available prototype glasses (Rauh, 1999; Syrrakou et al., 2005, 2006; Papaefthimiou et al., 2006a, b; Assimakopoulos et al., 2007; Kraft and Rottmann, 2009; Piccolo et al., 2009). For the present study the data were chosen from $\mathrm{SAGE}^{\mathrm{TM}}$, since this manufacturer provides the necessary detailed optical properties required for the simulation. The optical properties of the three studied glass types (single, double and double EC) are listed in Table 1, and they are: thermal transmission coefficient $(U)$, solar factor $(g)$, solar reflectivity $\left(\rho_{\text {solar }}\right)$, solar transmittance $\left(\tau_{\text {solar }}\right)$, solar absorptance $\left(\alpha_{\text {solar }}\right)$ and visual transmittance $\left(\tau_{v}\right)$. The data for EC glass corresponds to a laminated type with an air gap of $12.7 \mathrm{~mm}(0.5 \mathrm{in}$.) filled with air and argon (10\% and 90\% respectively).

The software "WINDOW 5.2" was used to compute the glass characteristics showed in Table 1 for different solar incidence angles. The computed values were then used in ESP-r.

The SAGE ${ }^{\mathrm{TM}}$ coatings where the solar energy is absorbed and reradiate are on the inside surface of the outside glass pane. The glass has also low-emissivity characteristics giving a positive contribution to the building heat conservation during wintertime.

The distance between the independent thermal zones (see Fig. 1) was set to avoid shadowing. In each thermal zone to the window has a specific type of glazing: single glazing, double glazing and double EC glazing.

Occupancy diagrams, as well as lighting and equipment use patterns, were estimated based on the energy consumption breakdown of the reference building, obtained from an energy audit. The resulting diagrams are presented in Figs. 2 and 3. Occupancy was not considered on Sunday, and a constant value of $1 \%$ for lighting and equipment use was admitted.

From the energy audit carried out to the building, some average values were estimated to use in the test-cell model. Therefore, for equipment and lighting characterisation, the following maximum values for occupancy, lighting and equipment were estimated and considered for the simulation:

- $15 \mathrm{~m}^{2}$ /occupant -3 occupants $(240 \mathrm{~W}$ - sensible heat, $120 \mathrm{~W}$ - latent heat); 
Table 1

Physical properties of the three types of glasses analysed.

\begin{tabular}{|c|c|c|c|c|}
\hline \multirow[t]{2}{*}{ Properties } & \multirow[t]{2}{*}{$\begin{array}{l}\text { Single } \\
\text { Clear } 3 \mathrm{~mm}\end{array}$} & \multirow[t]{2}{*}{$\begin{array}{l}\text { Double } \\
\text { Clear }(4 \mathrm{~mm} / 12 \mathrm{~mm} / 4 \mathrm{~mm})\end{array}$} & \multicolumn{2}{|c|}{$\begin{array}{l}\text { Double EC } \\
\text { SAGE }^{\mathrm{TM}}(4 \mathrm{~mm} / 12 \mathrm{~mm} / 4 \mathrm{~mm})\end{array}$} \\
\hline & & & Clear & Coloured \\
\hline$\overline{U\left(\mathrm{~W} /\left(\mathrm{m}^{2} \mathrm{~K}\right)\right.}$ & 5.79 & 2.80 & 1.60 & \\
\hline$g_{\perp}$ & 0.86 & 0.75 & 0.48 & 0.090 \\
\hline$\rho_{\text {solar }, \perp}$ & 0.07 & 0.12 & 0.20 & 0.100 \\
\hline$\tau_{\text {solar, } \perp}$ & 0.82 & 0.67 & 0.40 & 0.015 \\
\hline$\alpha_{\text {solar, }, \perp}$ & 0.11 & 0.21 & 0.40 & 0.885 \\
\hline
\end{tabular}

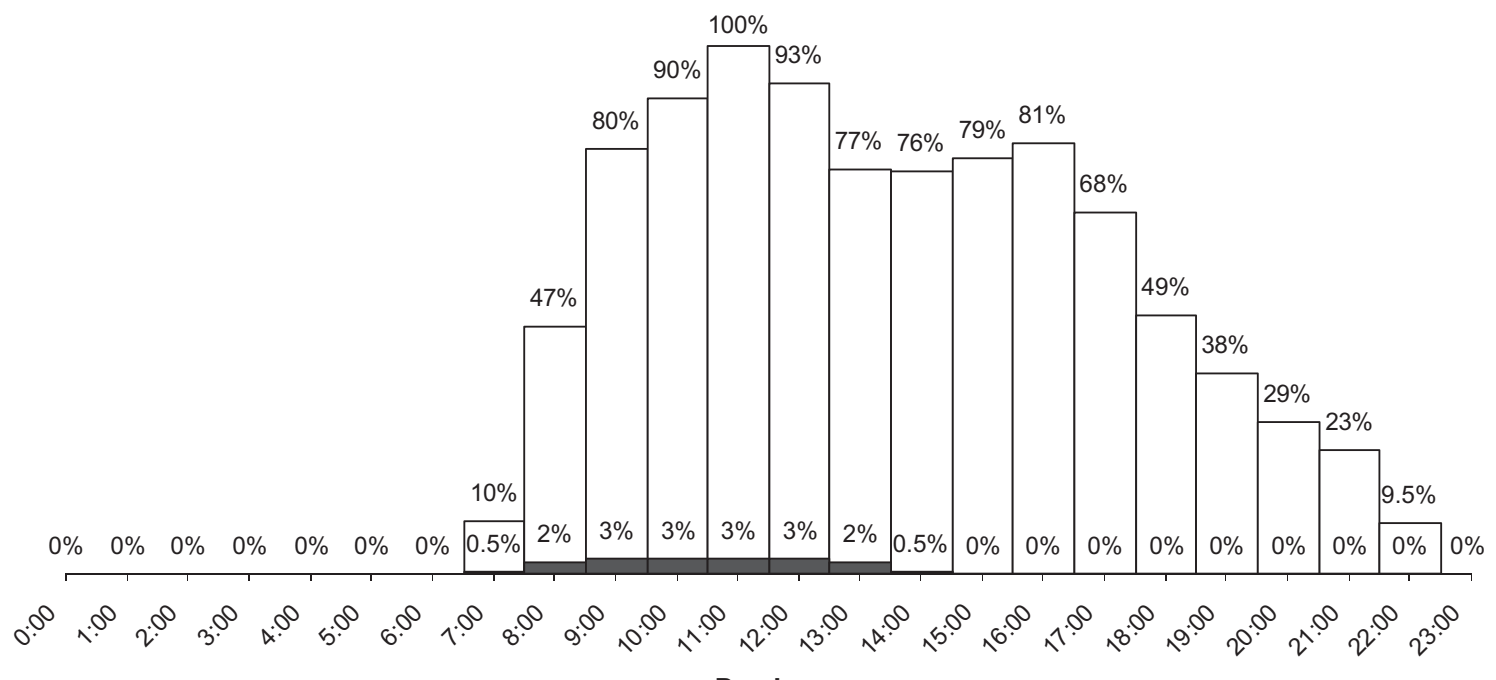

Day hour

$\square$ Weekdays $\square$ Saturday

Fig. 2. Occupancy diagrams for weekdays and Saturday.

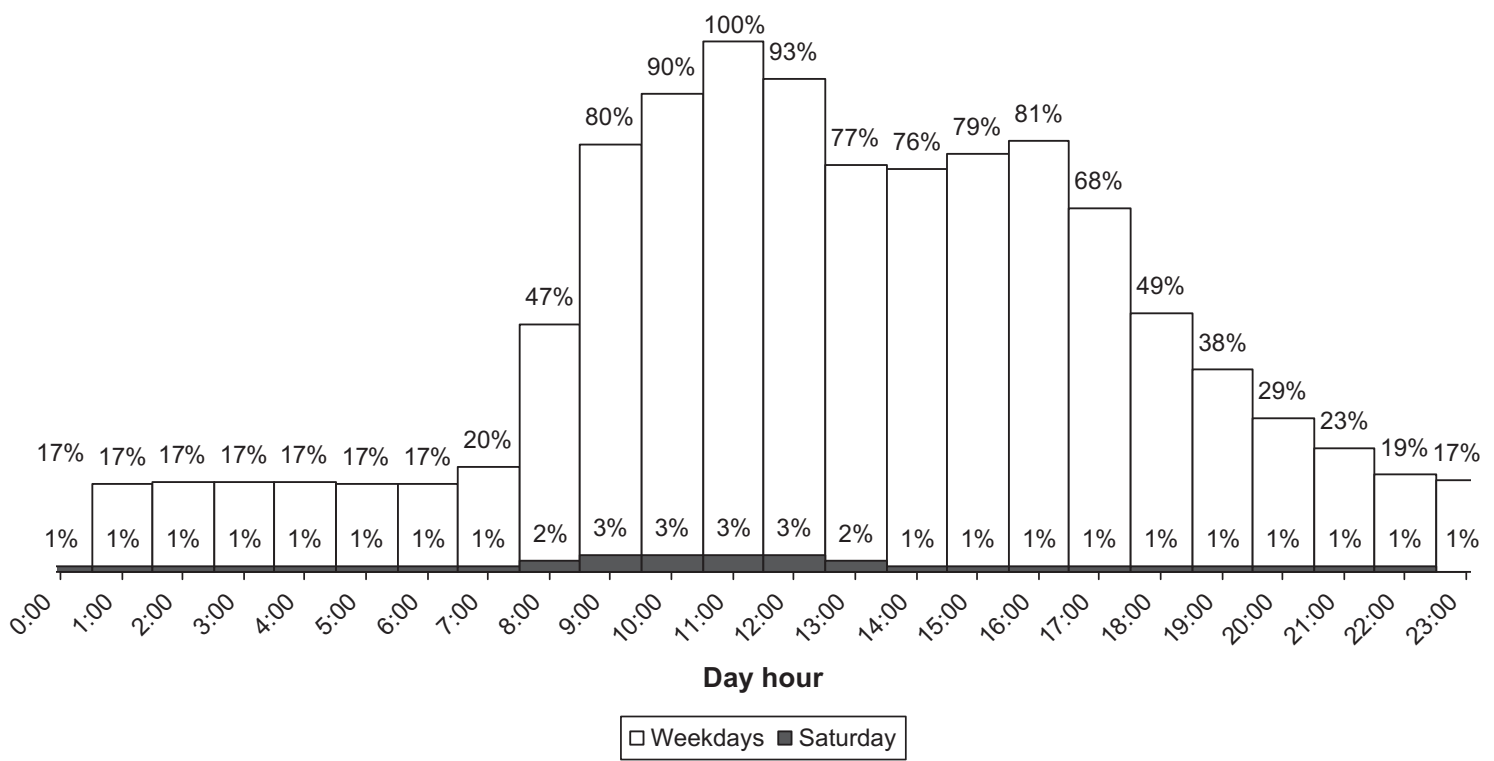

Fig. 3. Lighting and equipment diagrams for weekdays and Saturday. 
- $10 \mathrm{~W} / \mathrm{m}^{2}$ for lighting $(490 \mathrm{~W})$;

- $5 \mathrm{~W} / \mathrm{m}^{2}$ for equipment ( $\left.245 \mathrm{~W}\right)$.

Building simulations were performed to assess the building performance concerning heating and cooling needs. During occupied period it was considered as indoor temperature set-points $20^{\circ} \mathrm{C}$ for heating and $25^{\circ} \mathrm{C}$ for cooling. No indoor temperature control was considered during nonoccupied period.

\subsection{Control of the electrochromic glass}

Both the "Complex Fenestration Construction facility" and "Bi-directional model", also called "Black

state of the EC glass is determined according to the value of the control variable. Based on the instantaneous solar height and azimuth, in each step of the simulation, the optical properties of the EC glass were taken from the text file.

$$
\begin{aligned}
g_{\text {glass }}\left[\alpha_{\text {in }}\right]= & g_{\text {glass }}\left[0^{\circ}\right]\left(1-a_{\text {roos }}\left(\frac{\alpha_{\text {in }}}{90^{\circ}}\right)^{\alpha_{\text {roos }}}-b_{\text {roos }}\left(\frac{\alpha_{\text {in }}}{90^{\circ}}\right)^{\beta_{\text {roos }}}\right. \\
& \left.-c_{\text {roos }}\left(\frac{\alpha_{\text {in }}}{90^{\circ}}\right)^{\gamma_{\text {roos }}}\right) \\
\tau_{\text {sol,glass }}\left[\alpha_{\text {in }}\right] \approx & \tau_{\text {sol, glass }}\left[0^{\circ}\right]\left(1-a_{\text {roos }}\left(\frac{\alpha_{\text {in }}}{90^{\circ}}\right)^{\alpha_{\text {roos }}}\right. \\
& \left.-b_{\text {roos }}\left(\frac{\alpha_{\text {in }}}{90^{\circ}}\right)^{\beta_{\text {roos }}}-c_{\text {roos }}\left(\frac{\alpha_{\text {in }}}{90^{\circ}}\right)^{\gamma_{\text {roos }}}\right)
\end{aligned}
$$

$\rho_{\text {sol,glass }}\left(\alpha_{\text {in }}\right) \approx\left\{\begin{array}{l}1-\tau_{\text {sol, glass }}\left(\alpha_{\text {in }}\right)-\underbrace{\left\lfloor 1-\rho_{\text {sol, glass }}\left(\alpha_{\text {in }}=0^{\circ}\right)-\tau_{\text {sol,glass }}\left(\alpha_{\text {in }}=0^{\circ}\right)\right\rfloor}_{\text {absortivity for normalincidence } \alpha\left(\alpha_{\text {in }}=0^{\circ}\right)} \\ 1-\tau_{\text {sol,glass }}\left(\alpha_{\text {in }}\right)-\alpha\left(\alpha_{\text {in }}=0^{\circ}\right) \frac{\alpha_{\text {in }}-90^{\circ}}{15^{\circ}} \text { if } \alpha_{\text {in }}>75^{\circ}\end{array}\right.$

Box Model" (BBM), can be used to model windows with shading blinds in ESP-r and adapted for EC glasses modelling. For the present study it was used BBM due to its more modelling flexibility.

The modulation of the electrochromic glass was achieved by the adaptation of a module designed for ESP-r entitled "Black Box Model" to simulate the use of shutters (Frontini et al., 2009). The parameterization of the EC Glass in the "Black Box Model" consists in the creation of a file containing the optical properties of the glass. Although the control of the state of the EC glass can be done continuously, in this modulation it is only possible to define a set of six possible states of colouration, including the clear state (State 1) and full-colour (Condition 6). These six states were defined with the list of properties shown in Fig. 4.

A text file for each of the geographical orientations of EC glazed windows (East, South and West) (Frontini et al., 2009) was prepared for each of the glass states containing the relevant optical properties (solar factor, $g$, solar transmittance, $\tau_{\text {solar }}$, and solar reflectivity, $\rho_{\text {solar }}$ ) in a format recognized by the simulator. The formulation used (see Eqs. (1)-(4)) is based on the equations from Rosenfeld (1996), Roos et al. (2000, 2011), Kuhn (2006) and Kuhn et al. (2011), validated by Platzer (2000), Rosenfeld et al. (2000), Karlsson and Roos (2000), Roos et al. (2000) and Karlsson et al. (2001). Based on the parameters $a_{\text {roos }}, b_{\text {roos }}, c_{\text {roos }}, \alpha_{\text {roos }}, \beta_{\text {roos }}$ e $\gamma_{\text {roos }}$ presented in Table 2 the values of $\tau_{\text {solar }}, g$ and $\rho_{\text {solar }}$, for the solar azimuth range of $\left[-90^{\circ}, 90^{\circ}\right]$ and solar height range of $\left[-90^{\circ}, 90^{\circ}\right]$, were computed with increments of $5^{\circ}$.

Each text file has the values of $\tau_{\text {solar }}, g$ and $\rho_{\text {solar }}$ for the solar incidence range in each of the six discrete states defined for EC glass. During the simulation process, the $\alpha_{\text {in }}\left(\alpha_{s}, \phi_{f}\right)=\arccos \left(\cos \left(\alpha_{s}\right) \cos \left(\phi_{f}\right)\right)$

The "Black Box Model" has five possible glazing control options (Frontini et al., 2009), namely: zone air temperature; outside air temperature; incident radiation on an outside surface; level of zone illuminance and; other zone air temperature.

According to the literature review the duration of the transition from a clear state to a complete coloured state is about to $20 \mathrm{~min}$ in a glazed surface with one square meter. This duration increases to about $108 \mathrm{~min}$ in the simulated glazed surface of $5.4 \mathrm{~m}^{2}$. The EC glazing control should be done at a slow transition frequency, in order to avoid early deterioration of the glass properties. So, EC glazing control systems should react with a certain delay, avoiding short stimulus periods, such as momentary cloudy sky due to fast and random passage of clouds. Besides, thermal behaviour time constant in older buildings is normally very high, which leads to slow variations in terms of indoor thermal comfort (Roos et al., 2005b). Based on the previous assumptions, it was chosen a simulation time step of one hour also used by Roos et al. (2005b).

Following the criterion of Roos et al. (2005b) an hourly time step was adopted for the dynamic simulations, which is considered adequate for operation and control conditions of the $\mathrm{EC}$ windows.

The transition between states of EC glass can be made according to several variables. In previous works (Tavares et al., 2011, 2014) several control options were analysed - indoor temperature, outdoor temperature and solar radiation incident on the glass. Incident radiation showed to lead to the best results in Mediterranean climates. In the present study the objective was to determine the best transition thresholds that must be chosen to 


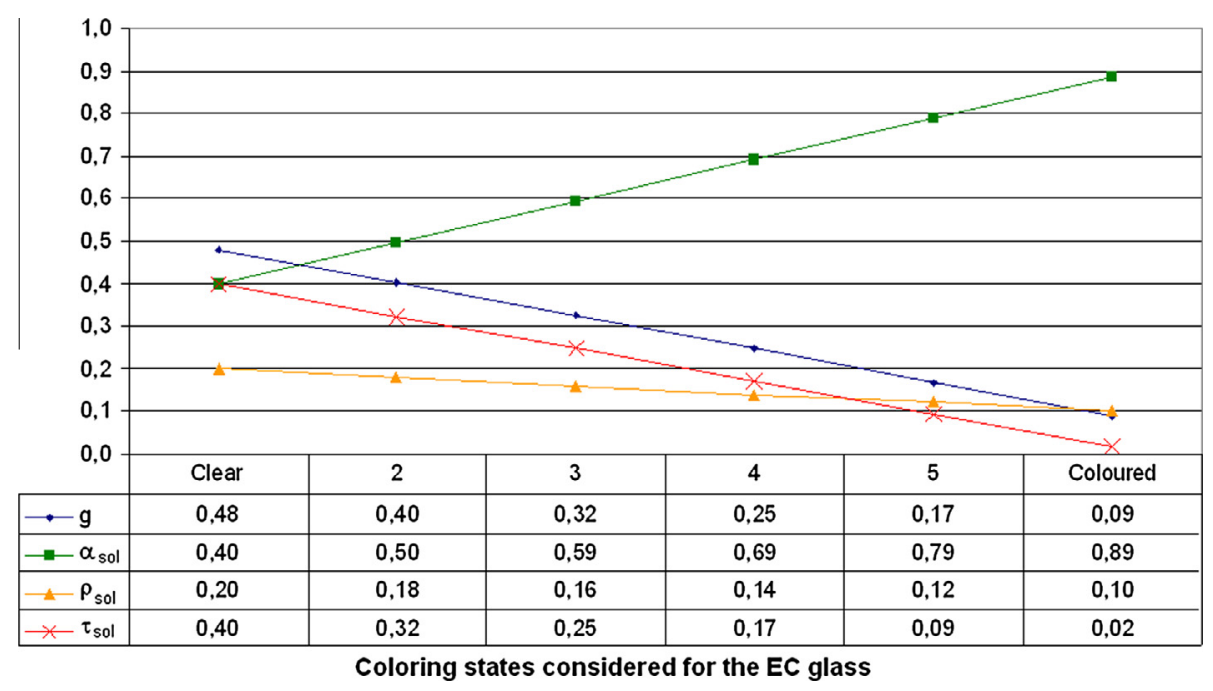

Fig. 4. Optical properties, for normal incidence, of the six states of the EC glass.

Table 2

Parameters used to calculate $\left(\tau_{\mathrm{so} \_} g \_\rho_{\mathrm{sol}}\right)$.

\begin{tabular}{lll}
\hline Parameters & Value & Notes \\
\hline$p_{\text {roos }}$ & 2 & Number of glass panes separated by an air layer \\
$q_{\text {roos }}$ & 1.00 & Fixed parameter: 1 (for EC glasses) \\
$a_{\text {roos }}$ & 8.00 & Fixed parameter \\
$b_{\text {roos }}=0.25 / q_{\text {roos }}$ & 0.25 & Fixed parameter \\
$c_{\text {roos }}=1-a_{\text {roos }}-b_{\text {roos }}$ & -7.25 & Fixed parameter \\
$\alpha_{\text {roos }}=5.2+0.7 \times q_{\text {roos }}$ & 5.90 & Fixed parameter \\
$\beta_{\text {roos }}=2$ & 2.00 & Fixed parameter \\
$\gamma_{\text {roos }}=\left(5.26+0.06 \times p_{\text {roos }}\right)+\left(0.73+0.04 \times p_{\text {roos }}\right) \times$ & 6.19 & Fixed parameter \\
$\quad q_{\text {roos }}$ & & \\
$g\left(\alpha=0^{\circ}\right)$ & 0.48 & Variable parameter \\
$\tau_{\text {sol }}\left(\alpha=0^{\circ}\right)$ & 0.40 & Variable parameter \\
$\rho_{\text {sol }}\left(\alpha=0^{\circ}\right)$ & 0.20 & Variable parameter \\
$\alpha_{\text {sol }}\left(\alpha_{\text {in }}=0^{\circ}\right)$ & 0.40 & Fixed parameter $\left(\alpha_{\text {in }}-\right.$ solar incidence angle $)$ \\
$\phi$ & 0.00 & Orientation of the facade $\left(0^{\circ}=\right.$ South, positive West $)$ \\
$\phi_{s}$ & - & Variable parameter - solar azimuth angle $\left(0^{\circ}=\right.$ South, positive West $)$ \\
$\phi_{f}$ & - & Variable parameter $-\phi_{f}=\phi_{s}-\phi\left(f a c a d e\right.$ azimuth angle, $0^{\circ}$ parallel to facade \\
$\alpha_{s}$ & & normal $)$ \\
\hline
\end{tabular}

control the EC glass by incident radiation in Mediterranean climates, considering three different orientations, namely East, South and West facades. Consequently, several incident radiation thresholds were tested for each facade orientation in order to identify the adequate threshold for each facade in terms of energy consumption reduction.

A more detailed description of the model can be found in Tavares et al. (2014).

The transition control ranges considered for EC glasses are shown in Table 3, taking into account six discrete states in the ESP-r based model. The code in the first column defines the transition value for the totally coloured state, e.g., G50 corresponds to a transition to a totally coloured state with a $50 \mathrm{~W} / \mathrm{m}^{2}$ incident radiation. The second column contains the maximum solar radiation incident on the glass that turns it to the coloured state. The remaining columns show the intermediate transition state values, up to the totally clear state.

\section{Results and discussion}

The results are presented considering heating energy needs as positive values and cooling energy needs as negative values. Energy performance analysis is based on the comparison of energy needs for heating, cooling and annual (heating and cooling), between the reference case of a single glazed window and an EC glazed window. Computing the differences between the two cases, positive variations correspond to an increase of energy needs and negative variations correspond to energy need reductions provided by the EC technology.

\subsection{Validation of the EC model}

This section is devoted to present a verification of the implemented EC model. In the simulation three blocks were defined, all with West oriented windows and 
Table 3

EC glasses transition ranges state studied according to incident solar radiation (values in $\mathrm{W} / \mathrm{m}^{2}$ ).

\begin{tabular}{llrrrrr}
\hline $\begin{array}{l}\text { State } \rightarrow \\
\text { Code } \downarrow\end{array}$ & Coloured & \multicolumn{1}{l}{ 5 } & \multicolumn{2}{l}{3} & 2 & Clear \\
\hline G50 & 50 & 40 & 30 & 20 & 10 & 0 \\
G100 & 100 & 80 & 60 & 40 & 20 & 0 \\
G150 & 150 & 120 & 90 & 60 & 30 & 0 \\
G200 & 200 & 160 & 120 & 80 & 40 & 0 \\
G250 & 250 & 200 & 150 & 100 & 50 & 0 \\
G300 & 300 & 240 & 180 & 120 & 60 & 0 \\
G350 & 350 & 280 & 210 & 140 & 70 & 0 \\
G400 & 400 & 320 & 240 & 160 & 80 & 0 \\
G450 & 450 & 360 & 270 & 180 & 90 & 0 \\
G500 & 500 & 400 & 300 & 200 & 100 & 0 \\
G550 & 550 & 440 & 330 & 220 & 110 & 0 \\
G600 & 600 & 480 & 360 & 240 & 120 & 0 \\
G650 & 650 & 520 & 390 & 260 & 130 & 0 \\
G700 & 700 & 560 & 420 & 280 & 140 & 0 \\
G750 & 750 & 600 & 450 & 300 & 150 & 0 \\
\hline
\end{tabular}

considering single glass (block number 1), double glass (block number 2) and EC glass (block number 3). The simulations were made in free running mode, without space temperature control, allowing a better discussion of the solar energy that enters the spaces. The simulations also allow verifying the operation of the EC glass and its control by the incident solar radiation.

As demonstrating results it was select for the EC glass control the strategy G100 presented in Table 3, selected for the first approach in the present study following conclusions of Frontini et al. (2009).

Completing a first verification presented by Tavares et al. (2014), in Figs. 5 and 6 additional results are shown to help the evaluation of the implemented EC model. From the several outdoor and indoor parameters that can be presented it was selected for this verification exercise the normal beam and diffuse horizontal solar radiation and the solar radiation that enters in each zone (block) through the glass ("SolinEx"). In Fig. 5 are represented two days with low levels of solar radiation (January, 11 and 12) and in Fig. 6 two days with high levels of solar radiation (January, 13 and 14) of a winter week, according to the climate file for Coimbra.

From de results presented it can be observed that the control of the EC glass is working adequately. For instance, in the days presented in Fig. 5 the results show that when the solar radiation is low the EC glass acts like the double glass.

When the incident solar radiation is high the solar radiation entering the space is substantially reduced, resulting from the EC glass be activated to the coloured state (minimum solar factor or g-value), as can be observed in Fig. 6. From these results we can conclude on the effectiveness of the EC glasses in both situations and the verification of the EC glass model.

This analysis can be replicated for each one of the other year seasons. For example in summer days, always with high levels of incident solar radiation, the glass remains most of the time in the coloured state. In the intermediate seasons (spring and autumn) and also in winter (as presented) the glass will change from one state to another according the radiation presented in each day and at each hour.

\subsection{Reference window - single glass}

In Fig. 7 the results for the test cell with single glass window solution, are presented for the East (a), South (b) and West (c) facades. For the heating season the results corroborate the South window facade as the more adequate to maximize the useful winter solar gains. On the other hand, the window in this facade leads to the worst solution

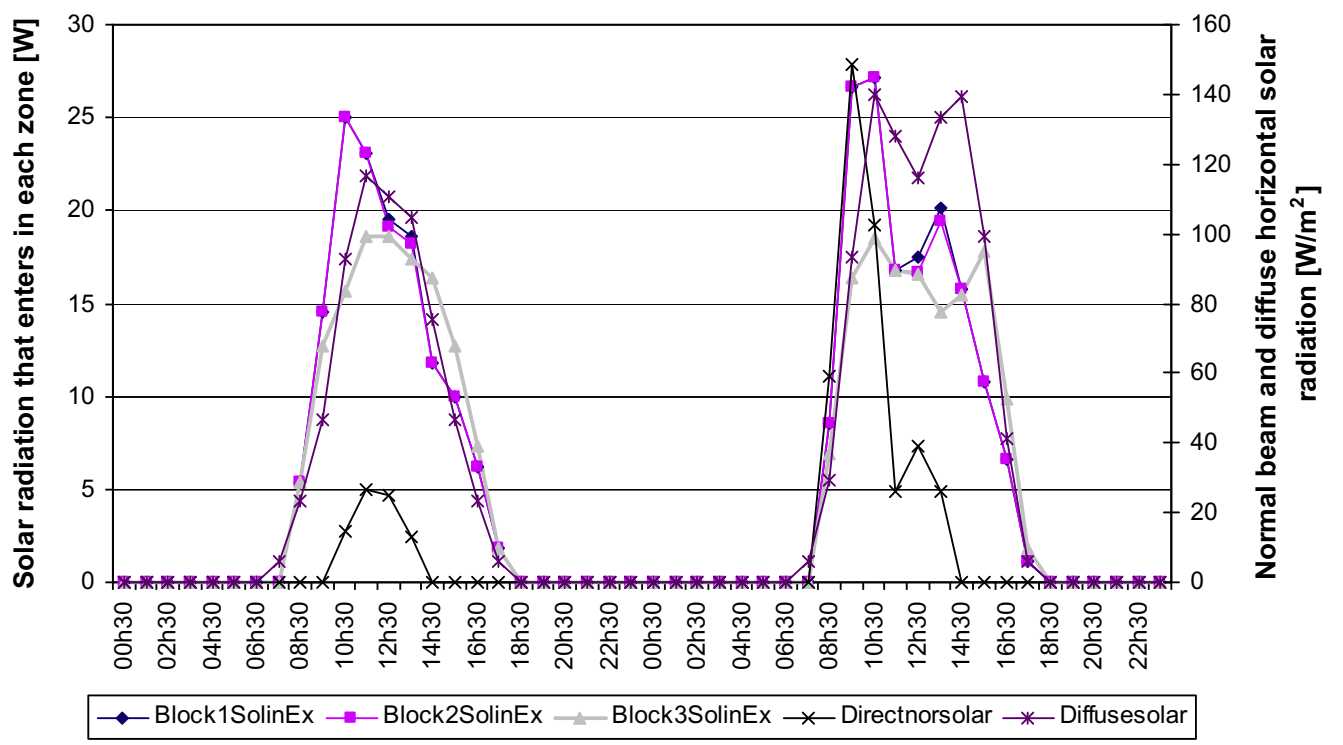

Fig. 5. Normal beam and diffuse horizontal solar radiation entering in each block by the window (January, day 11 and 12). 

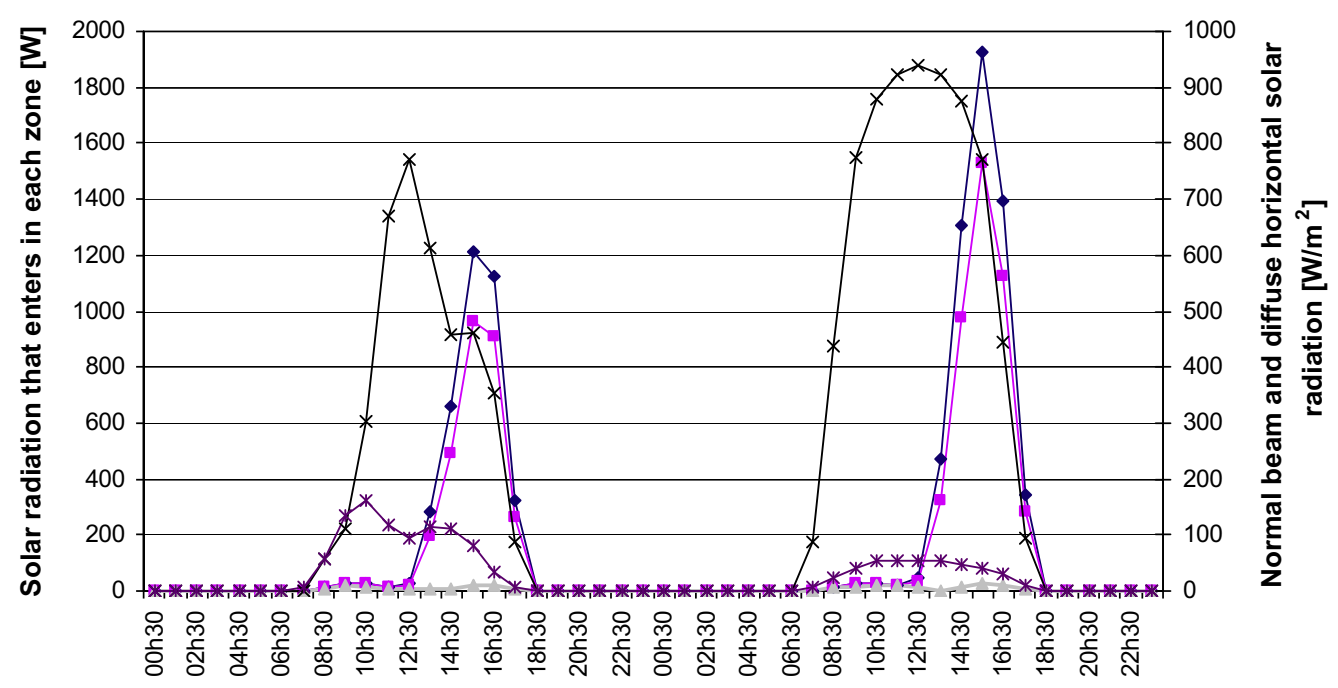

Fig. 6. Normal beam and diffuse horizontal solar radiation entering in each block by the window (January, day 13 and 14).
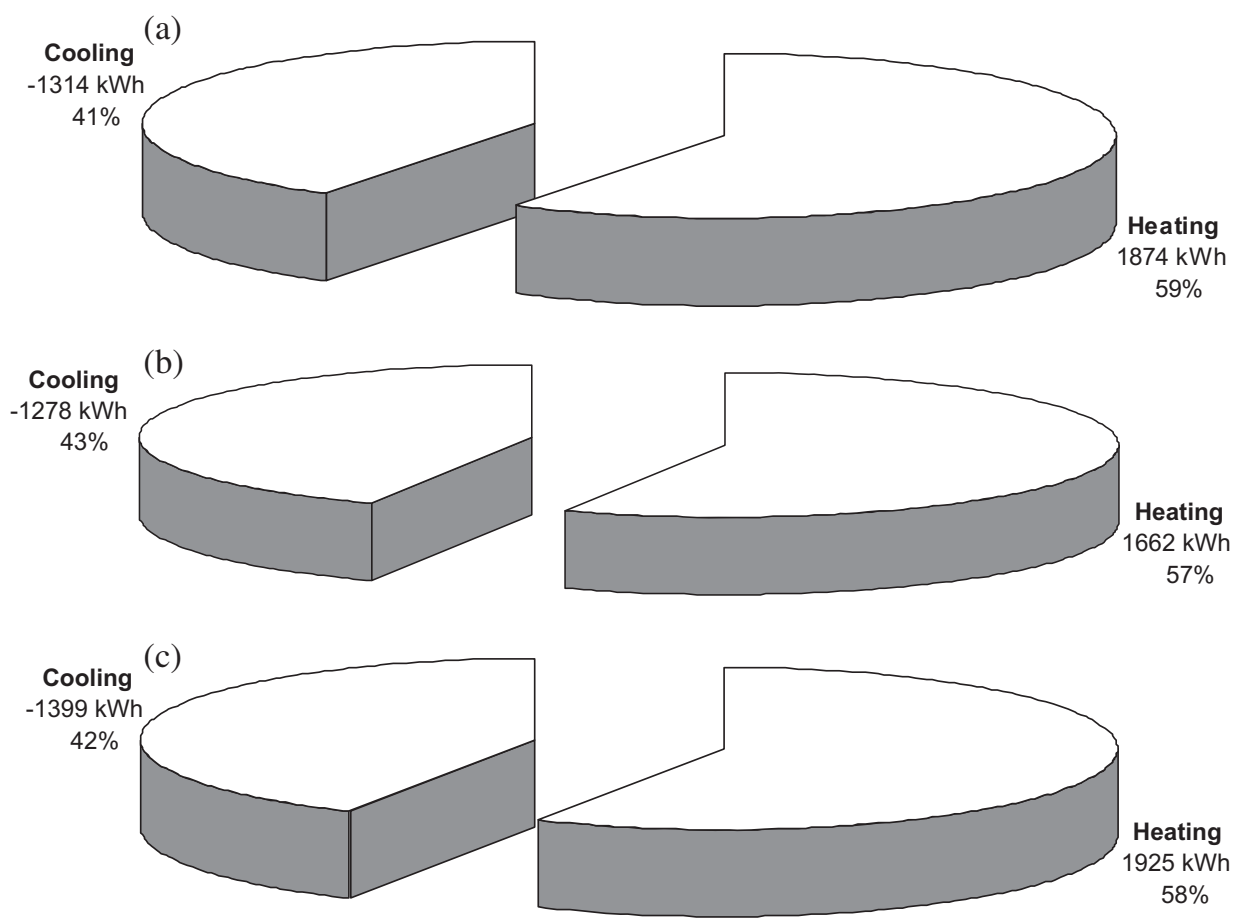

Fig. 7. Annual energy needs for single glass window in: (a) East Facade; (b) South Facade; and (c) West Facade.

during the cooling season, justified by the nonexistence of solar protections, like overhangs.

\subsection{Double glass window}

Fig. 8 shows the results of the double glass case. The comparison of results from Figs. 7 and 8 shown that double glass solution leads always to lower energy needs for heating, independently of the window facade orientation. The benefits are similar for the three facades $(-7.9$ to $8.0 \%$ ). In the cooling season the use of double glass results in an increase of the annual energy needs for cooling $(+3.6$ to $+3.7 \%$ ). These results are justified mainly by the differences of the $U$-value between these two glass types $\left(U_{\text {single }} \quad\right.$ glass $=5.79 \mathrm{~W} /\left(\mathrm{m}^{2} \mathrm{~K}\right) ; \quad U_{\text {double }}$ glass $=2.80 \mathrm{~W} /$ $\left.\left(\mathrm{m}^{2} \mathrm{~K}\right)\right)$ and by the facade orientation. In the heating season a low $U$-value leads to lower thermal losses but it penalizes the building energy performance during the cooling season.

The annual energy results show that the double glass solution is better than the single glass solution, independently of the facade (East facade: $-3.2 \%$; South facade: $-2.8 \%$; West facade: $-3.0 \%$ ). 

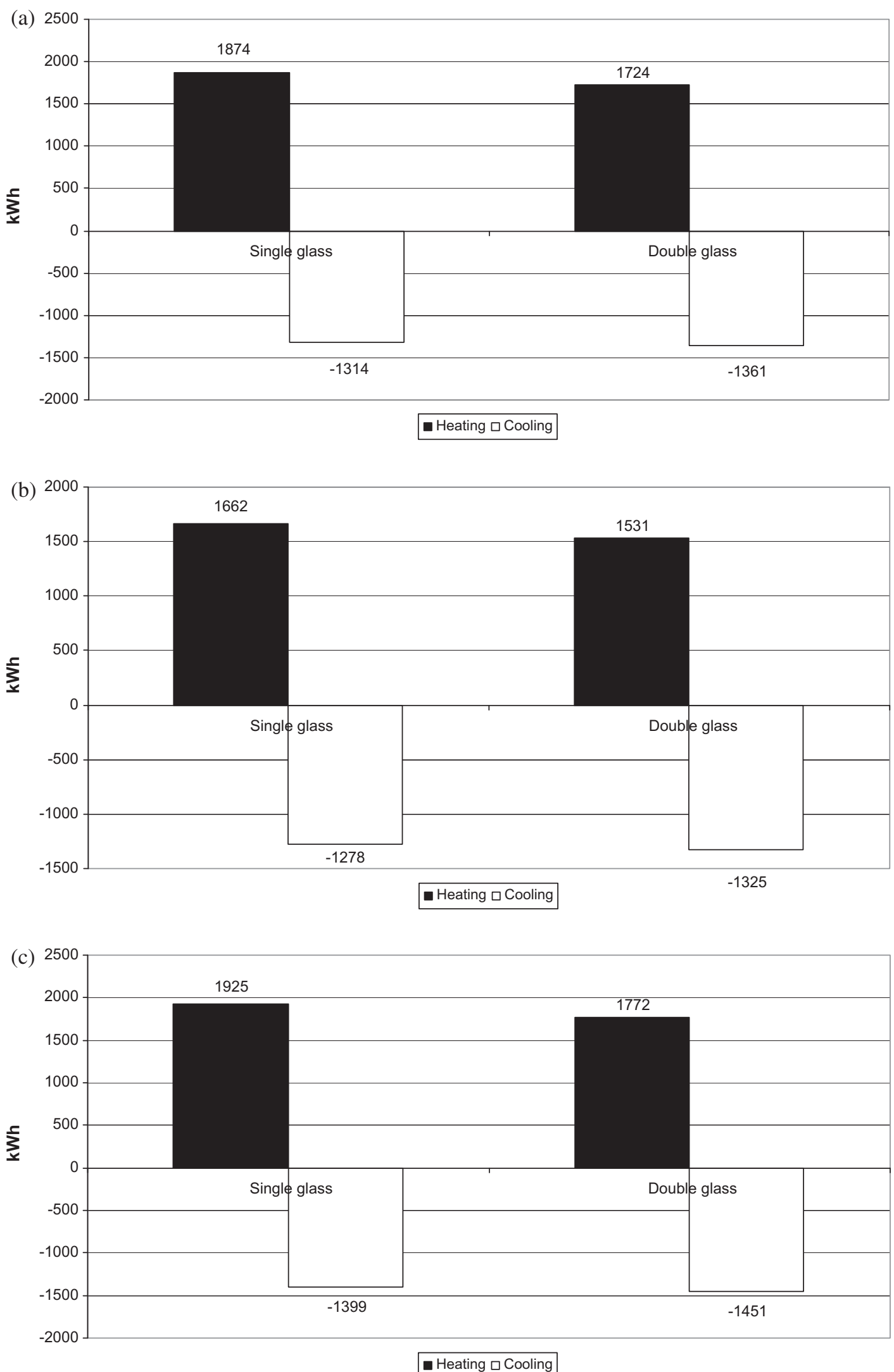

Fig. 8. Annual energy needs for double glass window in: (a) East Facade; (b) South Facade; and (c) West Facade. 
Table 4

Results of the sensitivity analysis of the EC glasses control range through incident solar radiation: (a) East facade; (b) South facade; (c) West facade.

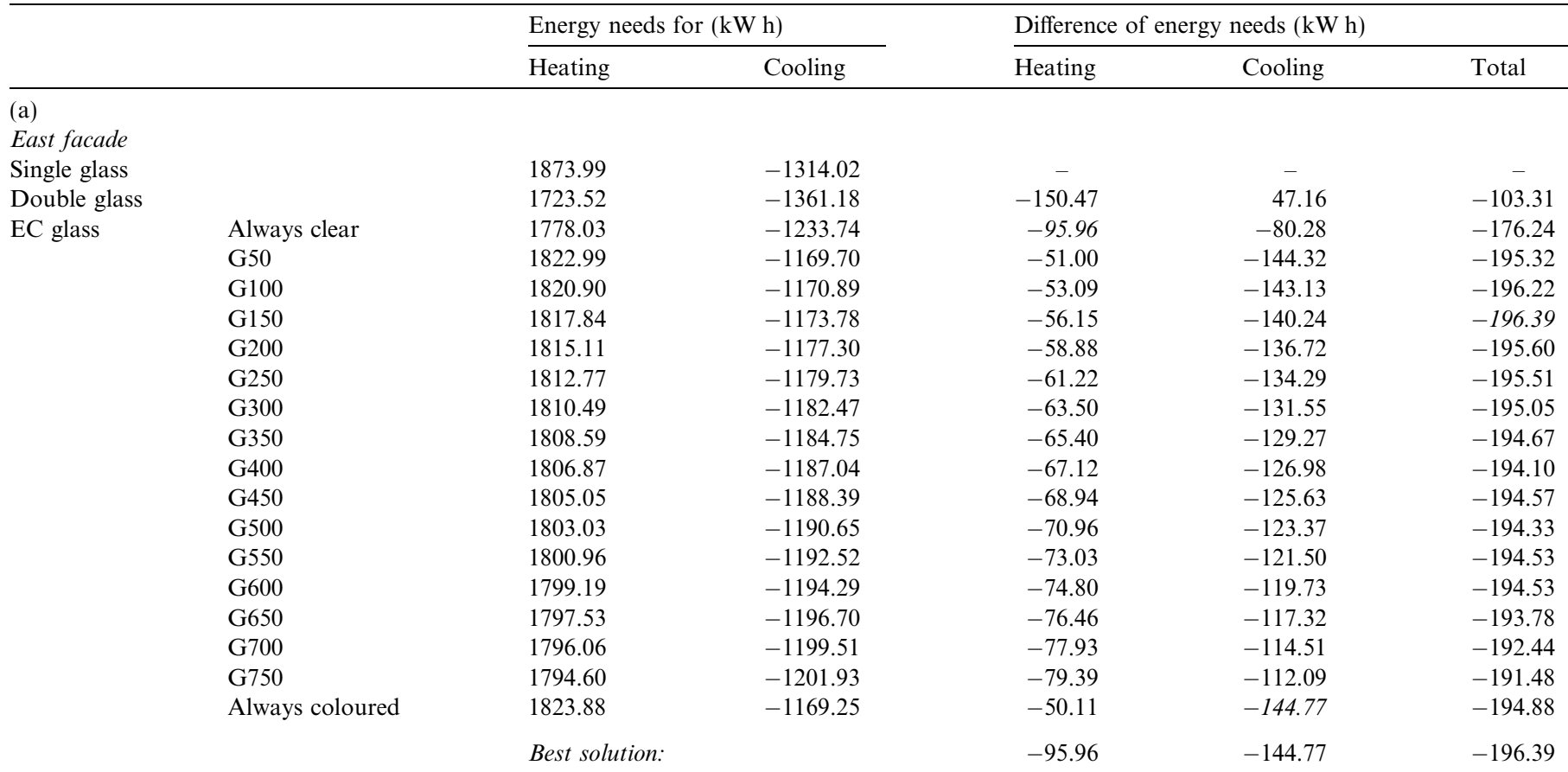

b)

South facade

Single glass

Double glass EC glass

c)

West facade

Single glass

Double glass

EC glass

Always clear
G50
G100
G150
G200
G250
G300
G350
G400
G450
G500
G750

Always coloured

1661.68

1531.21

1798.25

1883.46

1882.29

1880.73

1879.08

1877.62

1875.67

1873.99

1872.20

1870.41

1868.34

1855.30

1884.19

Best solution
$-1277.87$

$-1324.96$

$-1224.34$

$-1168.13$

$-1169.49$

$-1171.15$

$-1172.91$

$-1174.44$

$-1176.53$

$-1178.67$

$-1181.37$

$-1184.26$

$-1187.41$

$-1200.95$

$-1167.58$

$-130.47$

136.57

221.78

220.61

219.05

217.40

215.94

213.99

212.31

210.52

208.73

206.66

193.62

222.51

136.57

$$
\begin{array}{r}
47.09 \\
-53.53 \\
-109.74 \\
-108.38 \\
-106.72 \\
-104.96 \\
-103.43 \\
-101.34 \\
-99.20 \\
-96.50 \\
-93.61 \\
-90.46 \\
-76.92 \\
-110.29 \\
-110.29
\end{array}
$$

$-83.38$

\begin{tabular}{|c|c|c|c|c|c|}
\hline & 1924.54 & -1399.32 & - & - & - \\
\hline & 1771.51 & -1451.36 & -153.03 & 52.04 & -100.99 \\
\hline Always clear & 1772.46 & -1292.84 & -152.08 & -106.48 & -258.56 \\
\hline G50 & 1817.53 & -1190.68 & -107.01 & -208.64 & -315.65 \\
\hline G100 & 1815.42 & -1191.72 & -109.12 & -207.6 & -316.72 \\
\hline G150 & 1812.10 & -1194.49 & -112.44 & -204.83 & -317.27 \\
\hline G200 & 1809.00 & -1198.22 & -115.54 & -201.10 & -316.64 \\
\hline $\mathrm{G} 250$ & 1806.53 & -1201.20 & -118.01 & -198.12 & -316.13 \\
\hline G300 & 1803.98 & -1203.92 & -120.56 & -195.40 & -315.96 \\
\hline G350 & 1802.04 & -1205.85 & -122.50 & -193.47 & -315.97 \\
\hline G400 & 1800.10 & -1207.81 & -124.44 & -191.51 & -315.95 \\
\hline G450 & 1798.28 & -1209.75 & -126.26 & -189.57 & -315.83 \\
\hline G500 & 1796.23 & -1212.51 & -128.31 & -186.81 & -315.12 \\
\hline G750 & 1788.20 & -1228.57 & -136.34 & -170.75 & -307.09 \\
\hline \multirow[t]{2}{*}{ Always coloured } & 1818.44 & -1190.30 & -106.10 & -209.02 & -315.12 \\
\hline & \multicolumn{2}{|c|}{ Best solution: } & -152.08 & -209.02 & -317.27 \\
\hline
\end{tabular}

83.04

112.04

112.23

112.33

112.44

112.51

112.65

113.11

114.02

115.12

116.20

116.70

112.22

83.04 
Moreover, the small difference in heating energy results between single and double glazing (Figs. 7 and 8 ) is due to the moderate weather conditions during winter in Portugal.

\subsection{Results with EC glasses}

Table 4 summarizes the results of energy needs obtained for the EC glazed window case. Independently of the window orientation, the best decision in the heating season consists of always keeping the EC glass in the clear state, while in the cooling season it should be kept in the coloured state. However, the annual balance for the East and West facades show the best results are obtained with G150 control, result that is in accordance with the work of Gugliermetti et al. (2002). In Table 4(a, b and c) the minimum value in each column is highlighted in italics.

It is also evident that there is no advantage in using on the South facade, since it does not lead to additional annual energy savings.

The small differences obtained for annual energy savings on the East and West facades among the different control ranges show that the advantage of EC glasses utilization, controlled by incident solar radiation in East and West orientations is almost independent of the transition range choices. In fact, the results suggest that the utilization of EC glasses always generates energy savings comparing to static solutions using single or double glasses.

The results shown in this section confirm what was referred in Warner et al. (1992) that the use of solar gains in office buildings to control $\mathrm{EC}$ glasses leads to a reduction of cooling energy needs. However, in climates where buildings require active systems for heating, energy needs can be penalized by EC glass use. The final decision has to be based on a compromise between cooling energy savings and heating energy losses.

Studies aiming at assessing visual comfort refer that EC glasses may not solve glare problems (namely in non South orientations). Nevertheless, the use of internal shading devices could be a possible solution (Platzer, 2003a; Piccolo et al., 2009). For East and West orientations the internal shading devices must be vertical blades/louvers (Hastings and Crenshaw, 1977). During the heating season, glasses should be in the clear state most of the time, while on intermediate and cooling seasons the control should be set to the full coloured state. The energy savings with the consequent lower cooling load are considerably higher than the increase of energy consumption caused by artificial lighting (Platzer, 2003b), since cooling energy needs could only have a small increase due to artificial lighting internal gains.

\section{Conclusions}

This paper made a comparison between three glazing options: single glass, conventional double glazing and electrochromic glazing. Through energy simulation energy needs for heating and cooling were evaluated, showing which situations reveal advantages of using glasses with controllable properties (EC Glass) and static properties (single and double standard).

Energy use variations caused by the use of EC glasses were calculated as differences of energy requirements for heating, cooling and annual energy needs against the base case situation of using single glass (reference). The use of EC glasses, due to its lower solar factor in the clear state (0.48) compared to conventional double glazing (0.75), leads to increased heating energy requirements compared to the use of conventional double glazing (current). However, considering the energy requirements for cooling, the savings obtained by the use of EC glass with a solar factor of 0.09 in the coloured state are higher. The higher the cooling loads, the greater are the savings caused by the use of EC glass. Therefore, a balance between energy losses and thermal gains in heating and cooling seasons should be done.

Regardless of the type of glass used, the energy needs for heating and cooling vary from facade to facade, since the orientation is a factor of great importance in solar gains. The comparison of glasses with dynamic properties (EC Glass) with glasses with static properties (single and conventional double glass) showed that there is an advantage in the use of EC windows in East and West facades, in order to reduce energy requirements for air conditioning. For the South facade conventional double glazing should be used. In order to improve thermal comfort and reduce energy needs for heating and cooling, exterior horizontal fixed shading devices (Hastings and Crenshaw, 1977) must be used to protect south oriented glasses. Nevertheless, in building refurbishment this could not always be possible namely in the cases of historical and heritage buildings. Glazing solutions should be defined taking into account facade orientation. It can be concluded that the refurbishment strategies should depend on each facade orientation.

In the absence of outside shading, the case of the West orientation is the most advantageous for the application of electrochromic windows to reduce energy requirements both for the heating and for the cooling seasons. In the case of the East orientation, the use of electrochromic glass also proves to be advantageous, although with higher energy needs in comparison with their use on the West facade. The reduction of the annual energy needs on the West facade is about $62 \%$ higher than the reduction of the annual energy needs generated by the use of the EC glass on the East facade.

For the East and West facades the best strategy to control EC glass in the heating season consists of keeping EC glass always in the clear state, while in the cooling season the same applies to the coloured state, which shows to be the best option. In terms of annual energy balance, the best results for the East or West facade were obtained with G150 control, corresponding to a value of solar radiation incident on the glass of $150 \mathrm{~W} / \mathrm{m}^{2}$ to impose a total coloured state). However, results show only small variations of saved energy between the simulated control ranges. 
According to the results obtained, the use of the current double glass is a good solution to building retrofitting in Portugal and in similar Mediterranean climates for all facades, but the use of this kind of glass leads to less energy savings than the use of EC glass in the East and West facades.

EC glasses are an energy efficiency strategy that should be taken into consideration in existing buildings refurbishment, mainly for East and West oriented facades where the control of solar loads are particularly difficult and problematic. In this context, the use of building energy performance simulation software revealed to be a vital tool for decision support in the identification of technical viability conditions of the retrofitting solution.

\section{Acknowledgements}

This work has been framed under the Initiative Energy for Sustainability of the University of Coimbra and supported by the Energy and Mobility for Sustainable Regions Project (CENTRO-07-0224-FEDER-002004), co-funded by the European Regional Development Fund (ERDF) through the ûPrograma Operacional Regional do Centro 2007-2013 (PORC)ý, in the framework of the ûSistema de Apoio a Entidades do Sistema Científico e Tecnológico Nacionalý, and by the ûFundação para a Ciência e Tecnologiaý. It is also supported by the Portuguese ûFundação para a Ciência e a Tecnologiaý (FCT - Foundation for Science and Technology) under grant SFRH/ BD/35910/2007 and has also been partially supported by the Portuguese Foundation for Science and Technology under project grant UID/MULTI/00308/2013.

\section{References}

Aldawoud, Abdelsalam, 2013. Conventional fixed shading devices in comparison to an electrochromic glazing system in hot, dry climate. Energy Build. 59, 104-110. http://dx.doi.org/10.1016/j. enbuild.2012.12.031.

Argun, Avni A., Aubert, Pierre-Henri, Thompson, Barry C., Schwendeman, Irina, Gaupp, Carleton L., Hwang, Jungseek, Pinto, Nicholas J., Tanner, David B., MacDiarmid, Alan G.e, Reynolds, John R., 2004. Multicolored electrochromism in polymers: structures and devices. Chem. Mater. 16, 4401-4412.

Assimakopoulos, M.N., Tsangrassoulis, A., Santamouris, M., Guarracino, G., 2007. Comparing the energy performance of an electrochromic window under various control strategies. Build. Environ. 42, 2829-2834. http://dx.doi.org/10.1016/j.buildenv.2006.04.004.

Baetens, Ruben, Jelle, Bjørn Petter, Gustavsen, Arild, 2010. Properties, requirements and possibilities of smart windows for dynamic daylight and solar energy control in buildings: a state-of-the-art review. Sol. Energy Mater. Sol. Cells 94, 87-105. http://dx.doi.org/10.1016/ j.solmat.2009.08.021.

Bell, J.M., Matthews, J.P., Skryabin, I.L., 2002. Modelling switching of electrochromic devices - a route to successful large area device design. Solid State Ionics 152-153, 853-860. http://dx.doi.org/10.1016/S01672738(02)00385-5.

Burton, Simon, 2001. Energy efficient office refurbishment. James \& James (Science Publishers) Ltd (ISBN: 9781902916019).

Clarke, Joseph A., 2001. Energy Simulation in Building Design, 2aㅡ edição. Butterworth-Heinemann (ISBN: 0-7506-5082-6).
Clear, R.D., 2006. Summary results of visual comfort measurements at the electrochromic windows testbed. In: Annex of "Advancement of Electrochromic Windows". California Energy Commission (PIER, Publication number CEC-500-2006-052).

Clear, R.D., Inkarojrit, V., e Lee, E.S., 2006. Subject responses to electrochromic windows. Energy Build. 38, 758-779. http://dx.doi.org/ 10.1016/j.enbuild.2006.03.011.

Crawley, Drury B., Hand, Jon W., Kummert, Michaël, Griffith, Brent T., 2005a. Contrasting the capabilities of building energy performance simulation programs. In: Report made by Department of Energy (USA), Wisconsin University and Strathclyde University available at: $<$ http://apps1.eere.energy.gov/buildings/tools_directory/pdfs/contrasting the_capabilities_of_building energy_performance_simulation_programs_v1.0.pdf>.

Crawley, Drury B., Hand, Jon W., Kummert, Michaël, Griffith, Brent T., $2005 \mathrm{~b}$. Contrasting the capabilities of building energy performance simulation programs. In: Proceedings of "Building Simulation 2005, Ninth International IBPSA Conference”, Montreal, (Canada), 1518th August 2005.

Crawley, Drury B., Hand, Jon W., Kummert, Michaël, Griffith, Brent T., 2008. Contrasting the capabilities of building energy performance simulation programs. Build. Environ. 43, 661-673. http://dx.doi.org/ 10.1016/j.buildenv.2006.10.027.

DeForest, Nicholas, Shehabi, Arman, Garcia, Guillermo, Greenblatt, Jeffery, Masanet, Eric, Lee, Eleanor S., Selkowitz, Stephen, Milliron, Delia J., 2013. Regional performance targets for transparent nearinfrared switching electrochromic window glazings. Build. Environ. 61, 160-168. http://dx.doi.org/10.1016/j.buildenv.2012.12.004.

EControl, n/a. EControl-Glas. Web page accessed on 16th February 2012, $<$ http://www.econtrol-glas.de/en/home/ $>$.

Fernandes, L.L., Lee, E.S., Ward, G., 2013. Lighting energy savings potential of split-pane electrochromic windows controlled for daylighting with visual comfort. Energy Build. 61, 8-20. http://dx.doi.org/ 10.1016/j.enbuild.2012.10.057.

Freire, Roberto Zanetti, Mazuroski, Walter, Abadie, Marc Olivier, Mendes, Nathan, 2011. Capacitive effect on the heat transfer through building glazing systems. Appl. Energy 88, 4310-4319. http://dx.doi. org/10.1016/j.apenergy.2011.04.006.

Frontini, Francesco, Kuhn, Tilmann E., Herkel, Sebastian, Strachan, Paul, Kokogiannakis, Georgios, 2009, Implementation and applications of a new bi-directional solar modelling method for complex façades within the ESP-r building simulation program. In: Proceedings of "Eleventh International IBPSA Conference (Building Simulation 2009)", Glasgow (Scotland), 27-30th July 2009.

Gao, Tao, Jelle, Bjørn Petter, Ihara, Takeshi, Gustavsen, Arild, 2014 Insulating glazing units with silica aerogel granules: the impact of particle size. Appl. Energy 128, 27-34. http://dx.doi.org/10.1016/j. apenergy.2014.04.037.

Gesimat, 2012. Gesimat GmbH. Web page accessed on 21st March 2012, $<$ http://www.gesimat.de/>.

Gil-Lopez, Tomas, Gimenez-Molina, Carmen, 2013. Environmental, economic and energy analysis of double glazing with a circulating water chamber in residential buildings. Appl. Energy 101, 572-581. http://dx.doi.org/10.1016/j.apenergy.2012.06.055.

Granqvist, C.G., Green, S., Niklasson, G.A., Mlyuka, N.R., von Kræmer, S., Georén, , P., 2010. Advances in chromogenic materials and devices. Thin Solid Films 518, 3046-3053. http://dx.doi.org/10.1016/j. tsf.2009.08.058.

Gugliermetti, F., Passerini, G., Bisegna, F., 2002. Electrochromic windows as a chance to improve energy saving in office buildings in mild climates. In: Proceedings of "Sustainable Building 2002 Conference (SB 2002)", Rotterdam (Netherlands), 23-25th September 2002.

Hastings, S. Robert, Crenshaw, Richard W., 1977. Window design strategies to conserve energy. NBS Building Science Series 104. Report number NBS-BSS-104. National Bureau of Standards (Available at $<$ http://eric.ed.gov/?id=ED146695>).

Hee, W.J., Alghoul, M.A., Bakhtyar, B., Elayeb, OmKalthum, Shameri, M.A., Alrubaih, M.S., Sopian, K., 2015. The role of window glazing 
on daylighting and energy saving in buildings. Renew. Sustain. Energy Rev. 42, 323-343. http://dx.doi.org/10.1016/j.rser.2014.09.020.

Huang, Yu, Niu, Jian-lei, Chung, Tse-ming, 2014. Comprehensive analysis on thermal and daylighting performance of glazing and shading designs on office building envelope in cooling-dominant climates. Appl. Energy 134, 215-228. http://dx.doi.org/10.1016/j. apenergy.2014.07.100.

Jelle, Bjørn Petter, 2012. Accelerated climate ageing of building materials, components and structures in the laboratory. J. Mater. Sci. 47, 64756496. http://dx.doi.org/10.1007/s10853-012-6349-7.

Jelle, Bjørn Petter, 2013. Solar radiation glazing factors for window panes, glass structures and electrochromic windows in buildings - measurement and calculation. Sol. Energy Mater. Sol. Cells 116, 291-323. http://dx.doi.org/10.1016/j.solmat.2013.04.032.

Jonsson, Andreas, Roos, Arne, 2010. Evaluation of control strategies for different smart window combinations using computer simulations. Sol. Energy 84, 1-9. http://dx.doi.org/10.1016/j.solener.2009.10.021.

Karlsson, J., 2001. Control system and energy saving potential for switchable windows. In: Proceedings of " 7 th International IBPSA Conference", Rio de Janeiro (Brazil), 13-15th August 2001.

Karlsson, J., Roos, A., 2000. Modelling the angular behaviour of the total solar energy transmittance of windows. Sol. Energy 69 (4), 321-329. http://dx.doi.org/10.1016/S0038-092X(00)00083-9.

Karlsson, J., Rubin, M., Roos, A., 2001. Evaluation of predictive models for the angle-dependent total solar energy transmittance of glazing materials. Sol. Energy 71, 23-31. http://dx.doi.org/10.1016/S0038092X(01)00024-X.

Kelly, R., Painter, B., Mardaljevic, J., Irvine, K., 2013. Retrofit electrochromic glazing in an open plan office: a case study. In: Proceedings of "SLL/CIBSE International Lighting Conference", Dublin (Ireland), 12th April 2013.

Kraft, Alexander, Rottmann, Matthias, 2009. Properties, performance and current status of the laminated electrochromic glass of gesimat Sol. Energy Mater. Sol. Cells 93, 2088-2092. http://dx.doi.org/ 10.1016/j.solmat.2009.05.010.

Kuhn, Tilmann E., 2006. Solar control: a general evaluation method for façades with venetian blinds or other solar control systems. Energy Build. 38, 648-660. http://dx.doi.org/10.1016/j.enbuild.2005.10.002.

Kuhn, Tilmann, Herkel, E. Sebastian., Frontini, Francesco, Strachan, Paul, Kokogiannakis, Georgios, 2011. Solar control: a general method for modelling of solar gains through complex facades in building simulation programs. Energy Build. 43, 19-27. http://dx.doi.org/ 10.1016/j.enbuild.2010.07.015

Lee, E.S., DiBartolomeo, D.L., 2002. Application issues for large-area electrochromic windows in commercial buildings. Sol. Energy Mater. Sol. Cells 71, 465-491. http://dx.doi.org/10.1016/S0927-0248(01) 00101-5.

Lee, E.S., Claybaugh, E.S., LaFrance, M., 2012. End user impacts of automated electrochromic windows in a pilot retrofit application. Energy Build. 47, 267-284. http://dx.doi.org/10.1016/j. enbuild.2011.12.003.

Lee, Eleanor S., Dennis DiBartolomeo, L., Selkowitz, Stephen E., 2000. Electrochromic windows for commercial buildings: monitored results from a full-scale testbed. In: Proceedings of "2000 ACEEE Summer Study on Energy Efficiency in Buildings", Pacific Grove, California (USA), 20-25th August 2000.

Lee, Eleanor S., DiBartolomeo, Dennis L., Klems, Joseph H., Yazdanian, Mehry, Selkowitz, Stephen E., 2006. Monitored energy performance of electrochromic windows controlled for daylight and visual comfort. ASHRAE Trans. 112 (Part 2), 122-141.

Lin, C.-L., Wang, C.-C., 2015. Enhancement of electroactivity of platinum-tungsten trioxide nanocomposites with $\mathrm{NaOH}$-treated carbon support toward methanol oxidation reaction. Appl. Energy. http://dx.doi.org/10.1016/j.apenergy.2015.01.015.

Liu, Mingzhe, Wittchen, Kim Bjarne, Heiselberg, Per Kvols, 2015. Control strategies for intelligent glazed façade and their influence on energy and comfort performance of office buildings in Denmark. Appl. Energy 145, 43-51. http://dx.doi.org/10.1016/j.apenergy.2015.02.003.
Marinakis, Vangelis, Doukas, Haris, Karakosta, Charikleia, Psarras, John, 2013. An integrated system for buildings' energy-efficient automation: application in the tertiary sector. Appl. Energy 101, 6 14. http://dx.doi.org/10.1016/j.apenergy.2012.05.032.

Ochoa, Carlos E., Aries, Myriam B.C., van Loenen, Evert J., Hensen, Jan L.M., 2012. Considerations on design optimization criteria for windows providing low energy consumption and high visual comfort. Appl. Energy 95, 238-245. http://dx.doi.org/10.1016/j. apenergy.2012.02.042.

Palmero-Marrero, Ana I., Oliveira, Armando C., 2010. Effect of louver shading devices on building energy requirements. Appl. Energy 87, 2040-2049. http://dx.doi.org/10.1016/j.apenergy.2009.11.020.

Papaefthimiou, S., Leftheriotis, G., Yianoulis, P., Hyde, T.J., Eames, P. C., Fang, Y., Pennarun, P.-Y., Jannasch, P., 2006a. Development of electrochromic evacuated advanced glazing. Energy Build. 38, 1455 1467. http://dx.doi.org/10.1016/j.enbuild.2006.03.029.

Papaefthimiou, S., Syrrakou, E., Yianoulis, P., 2006b. Energy performance assessment of an electrochromic window. Thin Solid Films 502, 257-264. http://dx.doi.org/10.1016/j.tsf.2005.07.294.

Pfafferott, Jens, 2004. Enhancing the Design and Operation of Passive Cooling Concepts: Monitoring and Data Analysis in Four LowEnergy Office Buildings with Night Ventilation. Fraunhofer IRB Verlag (ISBN: 978-3-8167-6626-1).

Piccolo, A., Simone, F., 2009. Effect of switchable glazing on discomfort glare from windows. Build. Environ. 44, 1171-1180. http://dx.doi.org/ 10.1016/j.buildenv.2008.08.013

Piccolo, A., Pennisi, A., Simone, F., 2009. Daylighting performance of an electrochromic window in a small scale test-cell. Sol. Energy 83, 832 844. http://dx.doi.org/10.1016/j.solener.2008.11.013.

Platzer, W.J., 2000. The ALTSET project: measurement of angular properties for complex glazing. In: Proceedings of "EuroSun 2000 Conference", Copenhagen (Denmark), 19-22nd July 2000.

Platzer, W.J., 2003a. Architectural and Technical Guidelines - Handbook for the Use of Switchable Facades Technology". Fraunhofer Institute for Solar Energy Systems. Available at: <http://www.eu-swift.de/>.

Platzer, W.J., 2003b. Switchable Façade Technology - Energy Efficient Office Buildings with Smart Facades. In: Proceedings of "ISES 2003 Solar World Congress", Göteborg (Sweden), 14-19th June 2003.

Rahman, M.M., Rasul, M.G., Khan, M.M.K., 2010. Energy conservation measures in an institutional building in sub-tropical climate in Australia. Appl. Energy 87, 2994-3004. http://dx.doi.org/10.1016/j. apenergy.2010.04.005.

Rauh, R. David, 1999. Electrochromic windows: an overview. Electrochim. Acta 44, 3165-3176.

Ritchie, Justin, 2010. Energy Efficiency through Electrochromism and Gasochromism of Tungsten Oxide Films" (EECE 580, 17th March 2010). Web page accessed on 15th September 2011, <http://pt. scribd.com/doc/53333679/Electrochromics-for-Smart-Windows-forclass>.

Roos, A., Covalet, D., Fanton, X., Persson, M.-L., Platzer, W., Nielsen, T.R., Wilson, H.R., Zinzi, M., Köhl, M., Heck, M., Chevalier, B., 2005a. Energy performance of switchable glazing - IEA solar heating and cooling programme, Task 27. In: Proceedings of "10DBMC International Conférence on Durability of Building Materials and Components", Lyon (France), 17-20th April 2005.

Roos, Arne, Karisson, Joakim, van Nijnatten, Peter A., Hutchins, Michael G., Polato, Pietro, Nichelatti, Enrico, Montecchi, Marco, Olive, Francois, Anderson, Charles, 2001. Angular dependent optical properties of coated glazings - validation of two predictive algorithms. In: Lampert, Carl M., Granqvist, Claes-Göran, Lewis, Keith L. (orgs.), Solar and Switching Materials, Proceedings of SPIE, 4458, pp. 19-28.

Roos, Arne, Persson, Mari-Louise, Platzer, Werner, Köhl, Michael, 2005b. Energy efficiency of switchable glazing in office buildings. In: Proceedings of "Glass Processing Days 2005-9th international glass conference", Tampere (Finland), 17-20th June 2005

Roos, Arne, Polato, Pietro, Nijnatten, Peter A. Van, Hutchins, Michael G., Olive, Francois, Anderson, Charles, 2000. Angular-dependent 
optical properties of low-e and solar control windows - simulations versus measurements. Sol. Energy 69 (Suppl.), 15-26. http://dx.doi. org/10.1016/S0038-092X(01)00019-6, $\mathrm{n}^{\text {os }}$. 1-6.

Rosenfeld, J.L.J., 1996. On the calculation of the total solar energy transmittance of complex glazings. In: Proceedings of " 8 th International meeting on Transparent Insulation Material", Freiburg (Germany), 1996.

Rosenfeld, J.L.J., Platzer, W.J., Dijk, H. van, Maccari, A., 2000. Modelling the optical and thermal properties of advanced glazing: overview of recent developments. In: Proceedings of "EuroSun 2000 Conference", Copenhagen (Denmark), 19-22nd June 2000.

Rottmann, M., Kraft, A., Häusler, T., Fischer, U., Stenzel, H., 2007. Illuminance measurements and thermal analysis of test rooms equipped with high performance electrochromic glazing. In: Proceedings of "Glass Performance Days 2007-10th international glass conference", Tampere (Finland), 15-18th June 2007.

Rottmann, M., Kraft, A., Heckner, K.-H., Häusler, T., Fischer, U., Stenzel, H., 2005. Large area electrochromic safety glass; switching behaviour and transmission control of solar radiation. In: Proceedings of "Glass Processing Days 2005-9th international glass conference", Tampere (Finland), 17-20th June 2005.

Rowley, Natalie M., Mortimer, Roger J., 2002. New electrochromic materials. Sci. Prog. 85 (3), 243-262.

SAGE, n/a. SAGE Electrochromics. Web page accessed on 16th February 2012, <http://sageglass.com/>.

Sbar, Neil L., Podbelski, Lou, Yang, Hong Mo, Pease, Brad, 2012. Electrochromic dynamic windows for office buildings. Int. J. Sustain. Built. Environ. 1, 125-139. http://dx.doi.org/10.1016/j. ijsbe.2012.09.001.

Selkowitz, Stephen, Lee, Eleanor, 2004. Integrating automated shading and smart glazings with daylight controls. In: Proceedings of "International Symposium on Daylighting Buildings (IEA SHC TASK 31)", Torino (Italy), 21st September 2004.

Sottile, G.M., 2005. 2004 Survey of United States architects on the subject of switchable glazings. Mater. Sci. Eng., B 119, 240-245. http://dx.doi. org/10.1016/j.mseb.2004.12.077.

Sottile, Gregory M., 2002. Assessment of attitudes and expectations of switchable glass among united states window manufacturers. In: Proceedings of "45th Annual Technical Conference" (Society of Vacuum Coaters), Lake Buena Vista, Florida (USA), 13-18th April 2002.

Sullivan, R., Lee, E.S., Papamichael, K., Rubin, M., Selkowitz, S., 1994. Effect of switching control strategies on the energy performance of electrochromic windows. In: Proceedings of "SPIE International Symposium on Optical Materials Technology for Energy Efficiency and Solar Energy Conversion XIII", Friedrichsbau, Freiburg (Germany), 18-22nd April 1994.

Sullivan, R., Lee, E.S., Rubin, M., Selkowitz, S., 1996. The energy performance of electrochromic windows in heating dominated geographic locations. In: Proceedings of "SPIE Optical Materials Technology for Energy Efficiency and Solar Energy Conversion XV", Freiburg, (Germany), 16-19th September 1996.

Syrrakou, E., Papaefthimiou, S., Yianoulis, P., 2006. Eco-efficiency evaluation of a smart window prototype. Sci. Total Environ. 359, 267-282. http://dx.doi.org/10.1016/j.scitotenv.2005.10.023.

Syrrakou, E., Papaefthimiou, S., Skarpentzos, N., Yianoulis, P., 2005. Electrochromic windows: physical characteristics and environmental profile. Ionics 11, 281-288. http://dx.doi.org/10.1007/BF02430390.

Tavares, Paulo F., Gaspar, Adélio R., Martins, António G., Frontini, Francesco, 2014. Evaluation of electrochromic windows impact in the energy performance of buildings in mediterranean climates. Energy Policy 67, 68-81. http://dx.doi.org/10.1016/j.enpol.2013.07.038.

Tavares, Paulo Filipe, Martins, António Gomes, Gaspar, Adélio Rodrigues, 2011. Reduction building energy needs by the use of automation and control of electro-chromic windows. In: Proceedings/ Lectures Book (ISBN:978-84-95010-41-4), edited by ATECYR Associación Técnica Española de Climatización y Refrigeración, (and pen drive) of international conference: CLIMAMED 2011 - VI Mediterranean Congress of HVAC, 2-3rd June, 2011, Madrid, Spain, pp. 375-394.

Tavil, Asilhan, Lee, Eleanor S., 2005. The impact of overhang design on the performance of electrochromic windows. In: Proceedings of "International Solar Energy Society (ISES) Solar World Congress", Orlando, Florida (USA), 8-12th August 2005.

Tenner, A.D., Zonneveldt, L., 2002. Switchable facades and visual comfort. In: Proceedings of "Right Light 5", Nice (France), 29-31st May 2002.

Warner, Jeffrey L., Reilly, M. Susan, Selkowitz, Stephen E., Arasteh, Dariush K., 1992. Utility and economic benefits of electrochromic smart windows. In: Proceedings of "ACEEE 1992 Summer Study on Energy Efficiency in Buildings", Pacific Grove, California (USA), 30th August to 5th September 1992.

Zinzi, Michele, 2006. Office worker preferences of electrochromic windows: a pilot study. Build. Environ. 41, 1262-1273. http://dx.doi. org/10.1016/j.buildenv.2005.05.010. 